\title{
Pembatalan Suatu Perkawinan
}

\author{
Elvira Diba Fahlevi \\ Fakultas Hukum Universitas Trisakti Gedung H Lantai 2 Kampus A \\ Universitas Trisakti, J1.Kyai Tapa, Grogol, Jakarta 1440. \\ Email: elviraDf.30@gmail.com
}

\begin{tabular}{l}
$\frac{1}{\text { Artikel info }}$ \\
\hline Artikel history: \\
Diterima 01 Mei 2021 \\
Diterima dalam bentuk \\
revisi 10 Mei 2021 \\
Diterima dalam bentuk \\
revisi 17 Mei 2021
\end{tabular}

Keywords:

marriage annulment

Kata Kunci:

pembatalan perkawinan

\begin{abstract}
This study aims to discuss the annulment in a marriage both the causal factors, as a result of the law, who is the party who has the right to annul a marriage, and even about how the procedure of how to do the annulment of a marriage. Given that marriage is one of the acts of worship of all religious people to the god that a marriage should not be annulled, because a marriage is a legal act that is religious so it should not be played like that. Marriage also not only binds the relationship between a man and a woman only, but binds two large families, so that a marriage is not easy to annul. The annulment of a marriage begins only after the court decision has permanent legal force, and is effective from the date of the marriage. So it is considered important that there is prevention, so that there is no annulment of marriage. Therefore, steps are needed to be taken by government agencies such as the Office of Religious Affairs (KUA) in order to take action to anticipate the annulment of the marriage.
\end{abstract}

\begin{abstract}
Abstrak
Penelitian ini bertujuan untuk membahas mengenai pembatalan dalam suatu perkawinan baik faktor penyebab, akibat hukumnya, siapa saja pihak yang berhak melakukan pembatalan perkawinan, bahkan mengenai bagaimana prosedur cara melakukannya pembatalan dari suatu perkawinan. Mengingat perkawinan merupakan salah satu pelaksanaan ibadah semua umat beragama kepada tuhan yang tidak seharusnya suatu perkawinan itu dibatalkan, karena sebuah perkawinan itu merupakan perbuatan hukum yang bersifat religious sehingga tidak seharusnya seperti dipermainkan begitu. Perkawinan juga tidak hanya mengikat hubungan antara laki-laki dan perempuan saja, namun mengikat dua keluarga besar, sehingga sebuah perkawinan tidak mudah untuk dibatalkan. Pembatalan perkawinan dimulai hanya setelah keputusan pengadilan mempunyai kekuatan hukum tetap, dan efektif sejak tanggal perkawinan. Sehingga dipandang penting adanya pencegahan yang dilakukan, agar tidak terjadi pembatalan perkawinan. Oleh karena itu, diperlukan langkah-langkah yang harus diambil oleh instansi pemerintah seperti Kantor Urusan Agama (KUA) agar dapat mengambil tindakan untuk mengantisipasi terjadinya pembatalan pernikahan tersebut.
\end{abstract}

Coresponden author: Elvira Diba Fahlevi

Email: elviraDf.30@gmail.com artikel dengan akses terbuka dibawah lisensi

CC BY SA 


\section{Pendahuluan}

Perkawinan merupakan ikatan suci yang terkait dengan keimanan dan keyakinan kepada Allah, Ada pengertian perkawinan yang lainnya, diantaranya menurut Pasal 1 UndangUndang Nomor 1 Tahun 1974 tentang Perkawinan "Perkawinan ialah ikatan lahir bathin antara seorang pria dengan seorang wanita sebagai suami isteri dengan tujuan membentuk keluarga (rumah tangga) yang bahagia dan kekal berdasarkan Ketuhanan Yang Maha Esa." (Fikri et al., 2020).

Sejak zaman dahulu hingga sekarang, pernikahan telah menjadi kebutuhan hidup seluruh umat manusia, karena pernikahan merupakan masalah yang betul-betul terjadi untuk harus dibicarakan di dalam dan di luar peraturan hukum. Persetujuan bebas dari kedua belah pihak harus diperoleh dalam pernikahan tersebut. Artinya tidak ada paksaan antara laki-laki dan perempuan dalam perkawinan. Asas perkawinan menghendaki kebebasan kata sepakat antara kedua calon suami-istri, sesuai dengan Pasal 28 KUHPerdata (Kitab Undang-Undang Hukum Perdata). Perkawinan menurut (Subekti \& Tjitrosudibio, 2004) ialah, "Suatu ikatan perkawinan penting artinya bagi keturunan dan hubungan kekeluargaan, karena tujuan perkawinan adalah membentuk keluarga yang bahagia dan kekal, maka suami dan istri harus memperhatikan hak dan kewajibannya masing - masing."

Mengenai tujuan perkawinan menurut (Brata, 2019) ; telah dirumuskan bahwa setiap pasangan suami istri yang melangsungkan perkawinan pasti memiliki tujuan untuk membentuk keluarga (rumah tangga) yang bahagia dan kekal berdasarkan Ketuhanan Yang Maha Esa, maksudnya adalah bahwa perkawinan tidak cukup hanya dengan ikatan lahir saja atau ikatan batin saja tetapi harus kedua-duanya, terjalinnya ikatan lahir batin merupakan fondasi dalam membentuk keluarga bahagia dan kekal.

Untuk mencapai tujuan perkawinan maka perlu disusun peraturan perundang-undangan yang akan menjadi landasan dan syarat yang harus dipenuhi sebelum menikah. Salah satu prinsip yang tertuang dalam Undang-undang Perkawinan adalah perlindungan calon dan pendewasaan usia orang yang hendak menikah, artinya calon pasangan harus dewasa. Pasal 7 ayat (1) Undang-undang Perkawinan mengatur tentang kedewasaan tersebut, yang mengatur bahwa perkawinan hanya diperbolehkan bila pihak laki-laki mencapai usia 19 (sembilan belas) tahun dan perempuan berusia 16 (enam belas) tahun. Menetapkan syaat usia minimum yang harus dicapai oleh kedua belah pihak yang ingin menikah (Hardani, 2016).

Pembatalan perkawinan tidak seharusnya dilaksanakan karena pembatalan perkawinan sama dengan perceraian di mana memisahkan ikatan perkawinan yang telah sah menurut agama dan negara. Dalam pembatalan perkawinan sendiri mempunyai arti penting, pembatalan perkawinan tidak hanya berdampak pada pasangan suami isteri tetapi juga berdampak pada pihak-pihak yang lain yang yakni seperti harta benda dalam perkawinan seperti yang telah diatur dalam Pasal 35 sampai dengan Pasal 27 UU No.1 tahun 1974 tentang Perkawinan (Rusli, 2013), yaitu :

a. Harta bawaan, yang dimaksud ialah harta yang diperoleh suami isteri pada saat atau sebelum melakukan perkawinan, dapat dikatakan bahwa harta tersebut sebagai milik asli dari suami dan isteri. Pemilikan terhadap harta bawaan (harta pribadi) dijamin keberadaannya secara yuridis oleh hukum perkawinan. 
b. Harta pribadi, yaitu harta yang diperoleh oleh suami atau isteri selama perkawinan berlangsung sebagai hadiah, hibah wasiat atau warisan yang diperoleh secara pribadi terlepas dari soal perkawinan

c. Harta bersama, yaitu harta yang diperoleh dalam masa perkawinan dalam kaitannya dengan hukum perkawinan, baik penerimaan itu lewat perantaraan isteri maupun lewat perantaraan suami. Harta ini diperoleh sebagai hasil karya dari suami isteri, suami atau isteri dalam kaitan dengan perkawinan.

Dengan ada pembatalan perkawinan, maka perkawinan yang telah dilaksanakan merupakan suatu perkawinan yang tidak sah atau dianggap perkawinan tersebut tidak pernah ada. Walaupun perkawinan yang telah terjadi tersebut dianggap tidak pernah ada, tidak memungkiri atau menghilangkan akibat hukum dalam perkawinan yang pernah dilaksanakan. Seperti hal-hal di atas, memang sangat rawan terjadi sehingga dipandang penting adanya pencegahan yang dilakukan, agar tidak terjadinya pembatalan perkawinan. Oleh karena itu, diperlukan langkah-langkah, seperti Kantor Urusan Agama (KUA), agar dapat mengambil tindakan untuk mengantisipasi pembatalan perkawinan dengan cara memanipulasi identitas kedua mempelai atau menentukan boleh tidaknya calon pengantin untuk menikah secara tidak lengkap. Menikah atau tidak, yang pada akhirnya membatalkan perkawinan, meskipun kuasa untuk menentukan batal atau tidaknya perkawinan itu merupakan kewenangan hakim pengadilan agama (Faisal, 2017).

\section{Metode Penelitian}

Penulis menggunakan metode penelitian guna memahami objek dari penulisan ini dilaksanakan dengan menggunakan metode Normatif dan Studi Kepustakaan dengan melakukan penelusuran literatur atau data-data maupun buku-buku yang di kumpulkan, serta Metode pendekatan yang digunakan pada penelitian ini berbentuk Deskriptif yaitu metode penelitian dimaksudkan untuk mendapatkan saran-saran mengenai apa yang harus dilakukan untuk mengatasi masalah tertentu, dengan metode ini maka data-data yang dipakai dalam penulisan ini adalah data sekunder.

\section{Hasil dan Pembahasan}

Ada alasan-alasan yang dapat digunakan untuk menuntut pembatalan suatu perkawinan. Adapun Alasan Untuk Menuntut Pembatalan Perkawinan Berdasarkan KUHPerdata :

a. Bigami (Pasal 86 ayat 1, 27 KUHPerdata)

Bigami adalah bentuk perkawinan, dimana seorang laki-laki mengawini dua perempuan atau lebih dalam masa yang sama dan semuanya bersaudara.

Hak menuntut pembatalan diberikan KUHPerdata kepada :

1) Bekas suami dari perkawinan terdahulu

2) Suami atau isteri sendiri, berhubungn dengan kemungkinan dilakukannya bigami oleh suami-isteri dengan itikad baik (artinya tidak mengetahui adanya cacat).

3) Keluarga sedarah dalam garis lurus ke atas

4) Mereka yang mempunyai kepentingan (Pasal 93 KUHPerdata);

5) Jaksa/Penuntut Umum (Pasal 94 KUHPerdata). Jaksa dalam hal ini ikut campur karena tersangkut kepentingan umum. 
b. Tidak Adanya Persetujuan Bebas dari Suami Isteri atau salah seorang dari mereka itu (Pasal 87, 28 KUHPerdata)

Cacat tanpa tidak adanya kebebasan dalam memberikan persetujuan dapat timbul manakala dilakukan paksaan terhadap calon suami-isteri atau terhadap calon suami atau isteri, demikian pula jika terjadi kekhilafan mengenai orang baik itu menyangkut diri calon suami atau calon isteri, Kekhilafan sebagai dasar dari pada cacat pada syarat persetujuan bebas sebagaimana dimaksud di atas bersumber pada hukum Perancis dan berasal dari hukum Kanonik. Apakah yang dimaksud dengan khilaf mengenai diri orang dalam hubungan ini ?

Khilaf menurut Scholten dalam bukunya : Handboek voor de beoefening van het Burgerlijk Recht Jilid I cet.ke 7 hal.96 dst. maka yurisprudensi dan ilmu hukum di Perancis dan negeri Belanda mengenai hal itu mengemukakan contoh:

1) Orang kawin dengan orang lain dari pada yang dimaksud misalnya yang dimaksud untuk kawin dengan $\mathrm{B}$, tetapi nyatanya perkawinan dilangsungkan dengan $\mathrm{C}$.

2) Seorang kawin dengan orang lain yang menggunakan surat-surat yang palsu sehingga perkawinan dilangsungkan dengan orang lain daripada orang yang dimaksud. Di Perancis hal itu dinamakan khilaf mengenai identitas civile.

Yang membahas mengenai khilaf tidak hanya Scholten dalam bukunya : Handboek voor de beoefening van het Burgerlijk Recht Jilid I cet.ke 7 hal.96 dst. Tetapi ada juga yang membahas dan berpendapat lain mengenai Khilaf yaitu Hukum Perdata Jerman dalam Pasal 1333 B.G.B. berpendirian lain. Keadaan-keadaan biologis dalam diri orang yang akan melangsungkan perkawinan seperti impotensi, penyakit kelamin, gila dil, merupakan juga alasan-alasan untuk menuntut pembatalan perkawinan, jadi sangat memperluas kemungkinan penuntutan pembatalan perkawinan. Dan juga Pasal 1334 B.G.B. dan Pasal 124,125 Swiss Civil Code.

Hak menuntut pembatalannya diberikan UU kepada :

Suami atau Isteri yang persetujuannya tidak bebas atau berada dalam keadaan khilaf. hak tersebut hanya dapat digunakan dalam jangka waktu 3 bulan dihitung sejak saat ia memperoleh kebebasannya kembali atau setelah diketahuinya ia berada dalam keadaan khilaf (Pasal 87 ayat 3 KUHPerdata) dalam mana suami dan isteri secara terus menerus hidup bersama sebagai suami-isteri.

c. Ketidak cakapan untuk memberikan persetujuan, karena berada di bawah pengampuan berdasarkan terganggu kesehatan akalnya (Pasal 88 KUHPerdata).

Hak untuk menuntut pembatalan diberikan kepada ayah, Ibu, keluarga sedarah yang lain, dalam garis lurus ke atas, saudara laki dan perempuan, paman, bibi, pengampu, jaksa. Setelah berakhirnya pengampuan yang berhak menuntut pembatalan hanya suami atau isteri yang bersangkutan, dan hal inipun hanya mungkin jika dalam waktu 6 bulan setelah berakhirnya pengampuan itu tidak ada hidup bersama.

d. Belum tercapainya usia yang ditentukan dalam undang- undang seperti dimuat dalam Pasal 29 KUHPerdata (Pasal 89 KUHPerdata).

Hak menuntut pembatalan diberikan kepada suami atau Isteri yang belum mencapai usia tersebut atau jaksa, tuntutan tersebut tidak lagi dapat dilakukan dalam hal-hal sebagai berikut : 1. Pada saat tuntutan diajukan suami atau isteri telah mencapai usia yang ditentukan oleh undang-undang 
2. jika calon isteri meskipun belum mencapai usia tersebut tetapi sudah mengandung atau dalam keadan hamil. Dalam ilmu hukum dikemukakan sebagai ratio dari pada ketentuan ini bahwa dengan ketentuan demikian itu dapat dijamin kedudukan anak tersebut sebagai anak sah.

3. Jika si suami masih terlalu muda untuk dianggap dapat melakukan hubungan kelamin, hal tersebut para sarjana hukum berpendapat bahwa tuntututan pembatalan perkawinan dapat dilakukan, karena keadaan sebaliknya akan memungkinkan pelanggaran terhadap kesetian terhadap perkawinan.

e. Pelanggaran terhadap larangan perkawinan dalam Pasal 30,31 KUHPerdata

- Pasal 30 KUHPerdata

"Perkawinan dilarang antara mereka, yang mana satu dengan yang lain mempunyai hubungan darah dalam garis ke atas maupun garis ke bawah, baik karena kelahiran yang sah maupun karena kelahiran yang tidak sah, atau karena perkawinan; dalam garis ke samping, antara kakak beradik laki perempuan, sah atau tidak sah.”

- Pasal 31 KUHPerdata

"Juga dilarang perkawinan:

1. Antara ipar laki-laki dan ipar perempuan, sah atau tidak sah, kecuali bila suami atau istri yang menyebabkan terjadinya periparan itu telah meninggal atau bila atas dasar ketidakhadiran si suami atau si istri telah diberikan izin oleh Hakim kepada suami atau istri yang tinggal untuk melakukan perkawinan lain

2. Antara paman dan atau paman orang tua dengan kemenakan perempuan kemenakan, demikian pula antara bibi atau bibi orang tua dengan kemenakan laki-laki kemenakan, yang sah atau tidak sah. Jika ada alasan-alasan penting, Presiden dengan memberikan dispensasi, berkuasa menghapuskan larangan yang tercantum dalam pasal ini."

f. Pelanggaran terhadap larangan perkawinan dalam Pasal 32 KUHPerdata

Pasal 32 KUHPerdata yaitu "Seseorang yang dengan keputusan pengadilan telah dinyatakan melakukan zina, sekali-kali tak diperbolehkan kawin dengan pasangan zinanya itu."

g. Pelanggaran terhadap larangan Pasal 33 KUHPerdata

Pasal 33 KUHPerdata yaitu "antara mereka, yang perkawinannya telah dibubarkan sesuai dengan ketentuan-ketentuan Pasal 199, nomor 3e atau 4e tak diperbolehkan untuk kedua kalinya diadakan perkawinan, melainkan setelah waktu satu tahun. semenjak pembubaran perkawinan mereka yang terakhir dibukukan dalam register-register Catatan Sipil."

Hak menuntut pembatalannya diberikan kepada :

1) Suami atau isteri sendiri

2) Orang tua dan para keluarga dalam garis lurus ke atas

3) Mereka yang berkepentingan

4) Jaksa (Pasal 90 KUHPerdata)

Pasal 90 KUHPerdata yaitu "Semua perkawinan yang dilakukan dengan melanggar ketentuan-ketentuan dalam pasal-pasal 30, 31, 32 dan 33, boleh dimintakan pembatalan, baik oleh suami istri itu sendiri, maupun oleh orang tua mereka atau keluarga sedarah mereka dalam garis ke atas, atau oleh siapa pun yang mempunyai kepentingan dengan pembatalan itu, ataupun oleh Kejaksaan" 


\section{h. Pelanggaran terhadap Pasal 35-40 KUHPerdata}

Hak menuntut pembatalan diberikan kepada mereka yang izin kawinnya harus dimintakan (Pasal 91 KUHPerdata). Hak ini menjadi gugur jika dalam jangka waktu 6 bulan tidak diajukan tuntutan pembatalan, dihitung sejak saat ia mengetahui pelanggaran tersebut, atau mereka yang mengesahkan perkawinan yang cacat itu baik secara tegas atau diam-diam. mereka itu mengesahkan Terhadap perkawinan yang dilangsungkan diluar negeri maka KUHPerdata mulai diperhitungkan sejak saat akta perkawinan yang bersangkutan didaftarkan menurut Pasal 84 KUHPerdata.

i. Ketidakwenangan Pejabat Catatan Sipil, tidak terpenuhinya syarat jumlah saksi atau tidak terpenuhinya syarat kedudukan sebagai saksi pada saat perkawinan dilangsungkan (Pasal 92 KUHPerdata).

Hak menuntut permbatalan perkawinan diberikan kepada suami atau isteri sendiri, para keluarga sedarah dalam garis lurus ke atas, wali, wali pengawas, mereka yang mempunyai kepentingan, jaksa. Suami atau isteri tidak lagi dapat menggunakan hak tersebut jika mereka itu tampak hidup bersama sebagai suami-isteri dan terdapat akta perkawinan dibuat dihadapan Pejabat Catatan Sipil.

j. Pelanggaran terhadap larangan dalam Pasal 70 KUHPerdata

Pasal 70 KUHPerdata yaitu :

“Apabila dilakukan pencegahan akan suatu perkawinan, maka pegawai catatan sipil tak diperbolehkan melangsungkan perkawinan itu, melainkan setelah disampaikan kepadanya suatu putusan Hakim yang telah memperoleh kekuatan mutlak atau suatu akta resmi, dengan mana pencegahan itu telah dihapuskan demikian itu atas ancaman hukuman membayar segala biaya, rugi dan bunga.

Jika terjadi kiranya, suatu perkawinan dilang- sungkan sebelum pencegahan dihapuskan, maka perkara mengenai pencegahan itu boleh dilanjut- kan, dan perkawinan boleh dinyatakan batal."

Selanjutnya sesuai dengan pokok pikiran di atas undang- undang dalam Pasal 93 KUHPerdata masih memuat suatu pembatasan lagi yaitu membatasi hak menuntut pembatalan mereka yang mempunyai kepentingan itu hanya dalam hal suami-isteri atau salah seorang dari mereka itu telah meninggal dunia dan jika terdapat pada mereka itu kepentingan yang mendesak. Ratio ketentuan ini ialah melindungi kebahagiaan suami-isteri terhadap tuntutan yang tidak wajar.

Jaksa juga tidak lagi dapat menuntut pembatalan perkawinan Jika perkawinan telah putus (Pasal 94 KUHPerdata), karena dalam hal itu tidak ada kepentingan umum lagi yang mengharuskan dilakukan tuntutan demikian (Sari, 2020).

Adapun Alasan Untuk Menuntut Pembatalan Perkawinan Berdasarkan UU No.1 Tahun 1974 :

1. Perkawinan yang tidak sesuai dengan syarat-syarat perkawinan (Pasal 22)

2. Suami/istri yang masih mempunyai ikatan perkawinan melakukan perkawinan tanpa seijin dan sepengetahuan pihak lainnya (Pasal 24)

3. Perkawinan dilangsungkan tanpa dihadiri oleh 2 (dua) orang saksi (Pasal 26)

4. Salah satu pihak memalsukan identitas dirinya. Identitas palsu misalnya tentang status, usia atau agama (Pasal 27)

5. Perkawinan dilangsungkan di bawah ancaman yang melanggar hukum (Pasal 27) 


\section{2) Tata Cara Pembatalan Suatu Perkawinan}

Menurut Pasal 38 ayat (2) Peraturan Pemerintah Nomor 9 Tahun 1975 tentang Pelaksanaan Undang-Undang Nomor 1 Tahun 1974 tentang Perkawinan menyebutkan bahwa : "Tata cara pengajuan permohonan pembatalan perkawinan dilakukan sesuai dengan tata cara pengajuan gugatan perceraian". Jadi, tata cara yang dipakai untuk permohonan pem batalan perkawinan sama dengan tata cara pengajuan permohonan perceraian.

Untuk lebih jelasnya, tata cara pembatalan perkawinan diuraikan sebagai berikut :

\section{Pengajuan gugatan}

Permohonan pembatalan suatu perkawinan diajukan oleh pihak-pihak yang berhak mengajukan kepada pengadilan yang daerah hukumnya yang meliputi tempat berlangsunganya perkawinan, atau di tempat kedua suami atau istri.

2. Pemanggilan

Di setiap persidangan, panggilan pengadilan harus dikeluarkan untuk para pihak ataupun para kuasa mereka. Panggilan pengadilan ditunjuk oleh juru sita pengadilan negeri setempat dan ketua pengadilan agama untuk pengadilan agama. Surat panggilan harus dibagikan kepada pribadi yang terkait. Jika panggilan tidak dapat ditemukan, maka panggilan dapat disampaikan melalui surat. Panggilan pengadilan harus dilakukan dengan cara yang tepat, oleh para pihak atau para kuasa mereka yang harus menerima panggilan pengadilan selambat-lambatnya 3 (tiga) hari sebelum sidang dibuka, dan tergugat juga harus melampirkan salinan gugatan. Selain panggilan pengadilan tersebut di atas, dalam hal domisili tergugat tidak jelas atau tidak memiliki tempat tinggal tetap, surat panggilan pengadilan dilakukan dengan melampirkan gugatan ke papan pengumuman pengadilan dengan 1 (satu) atau beberapa surat kabar atau media lain yang ditunjuk. Pengadilan melakukan sebanyak 2 (dua) kali dengan jangka waktu 1 (satu) bulan antara pengumuman pertama dan kedua. Jika tergugat bertempat tinggal di luar negeri, maka panggilan tersebut harus disampaikan oleh pengadilan melalui perwakilan Republik Indonesia setempat.

3. Persidangan

Dalam memeriksa gugatan untuk pembatalan perkawinan pengadilan harus melakukan selambat-lambatnya dalam waktu 30 (tiga puluh) hari setelah kepaniteraan menerima gugatan tersebut. Dalam menentukan tanggal persidangan, perlu diperhatikan tenggang waktu antara pemanggilan dan penerimaan panggilan tersebut oleh pihak yang berkepentingan. Khusus untuk gugatan dimana tergugat bertempat tinggal di luar negeri, maka ditetapkan sidang paling lambat 6 (enam) bulan sejak masuknya gugatan pembatalan perkawinan. Para pihak dalam perkara, yaitu suami dan istri, dapat membawa akta nikah dan dokumen lain yang diperlukan untuk mengikuti persidangan didampingi oleh kuasa hukumnya atau menyerahkan semuanya kepada kuasa hukumnya. Jika panggilan pengadilan yang sudah dibuat, tetapi tergugat atau pengacaranya tidak hadir, permintaan tersebut dapat diterima tanpa kehadiran tergugat kecuali jika gugatan tersebut tidak memiliki hak atau alasan. Pemeriksaan perkara gugatan untuk proses pembatalan pernikahan dilakukan dalam sidang tertutup. Kalaupun pemeriksaan gugatan pembatalan pernikahan dilakukan secara tertutup, namun pengucapan putusan gugatan tersebut harus dilakukan dalam sidang terbuka. Pembatalan pernikahan dimulai hanya setelah putusan pengadilan memiliki kekuatan hukum tetap, dan berlaku sejak tanggal pernikahan tersebut berlangsung.

4. Perdamaian 
Sebelum dan selama perkara gugatan belum diputuskan pengadilan harus berusaha mendamaikan kedua belah pihak yang berperkara. Apabila tercapai suatu perdamaian, maka tidak dapat diajukan gugatan pembatalan perkawinan yang baru berdasarkan alasan-alasan yang ada sebelum perdamaian dan telah diketahui oleh penggugat pada waktu tercapainya perdamaian.

\section{Kesimpulan}

Pembatalan perkawinan tidak seharusnya dilaksanakan karena tidak hanya berdampak pada suami isteri tetapi juga berdampak pada harta benda dalam perkawinan seperti yang telah diatur dalam Pasal 35 sampai dengan Pasal 27 UU No.1 tahun 1974 tentang Perkawinan, yaitu harta bawaan, harta pribadi dan harta bersama.

Batalnya suatu perkawinan dimulai setelah keputusan Pengadilan yang mempunyai kekuatan hukum yang tetap dan berlaku sejak saat berlangsungnya perkawinan. Sehingga diperlukanlah langkah-langkah yang harus ditempuh seperti lembaga pemerintah Kantor Urusan Agama (KUA) supaya dapat mengambil tindakan untuk mengantisipasi terjadinya pembatalan perkawinan.

Alasan yang dapat digunakan untuk menuntut pembatalan perkawinan berdasarkan KUHPerdata adalah:

a. Bigami (Pasal 86 ayat 127 KUHPerdata)

b. Karena Tidak Adanya Persetujuan Bebas dari Suami Isteri atau salah seorang dari mereka itu (Pasal 87, 28 KUHPerdata)

c. Ketidak cakapan untuk memberikan persetujuan (Pasal 88 KUHPerdata).

d. Belum tercapainya usia, Pasal 29 KUHPerdata (Pasal 89 KUHPerdata).

e. Pelanggaran terhadap larangan perkawinan dalam Pasal 30,31 KUHPerdata

f. Pelanggaran terhadap larangan Pasal 33 KUHPerdata

g. Ketidakwenangan Pejabat Catatan Sipil (Pasal 92 KUHPerdata).

h. Pelanggaran terhadap larangan dalam Pasal 70 KUHPerdata

Tata cara pembatalan suatu perkawinan: Berdasarkan Pasal 38 ayat (2) Peraturan Pemerintah Nomor 9 Tahun 1975 tentang Pelaksanaan Undang-Undang Nomor 1 Tahun 1974 tentang Perkawinan. 


\section{Bibliografi}

Brata, G. G. M. (2019). Analisis Pertimbangan Hakim Dalam Memutus Perkara Pembatalan Perkawinan. NOTARIUS, 12(1), 433-451.

Faisal, F. (2017). Pembatalan Perkawinan Dan Pencegahannya. Al-Qadha: Jurnal Hukum Islam Dan Perundang-Undangan, 4(1), 1-15.

Fikri, A. F., Iswanto, P., \& Muchtar, A. I. S. (2020). Kebolehan Pernikahan Beda Agama Menurut Undang-Undang Nomor 1 Tahun 1974 Dan Kompilasi Hukum Islam. Istinbath| Jurnal Penelitian Hukum Islam, 14(2), 77-114.

Hardani, S. (2016). Analisis Tentang Batas Umur Untuk Melangsungkan Perkawinan Menurut Perundang-Undangan Di Indonesia. An-Nida', 40(2), 126-139.

Rusli, T. (2013). Pembatalan Perkawinan Berdasarkan Undang-Undang Nomor 1 Tahun 1974 Tentang Perkawinan. Pranata Hukum, 8(2).

Sari, R. D. (2020). Tinjauan Yuridis Terhadap Putusan Pembatalan Yang Diajukan Oleh Pejabat Yang Berwenang Paska Putusnya Perkawinan Karena Kematian (Studi Terhadap Putusan Pengadilan Agama Nomor 3034/Pdt. G/2018/Pa. Badg). Universitas Muhammadiyah Malang.

Subekti, R., \& Tjitrosudibio, R. (2004). Kitab Undang-Undang Hukum Perdata: dengan tambahan Undang-Undang Pokok Agraria dan Undang-Undang Perkawinan. 